\title{
POSITION OF MEDICAL COLLEGES' STUDENTS IN RESPECT TO SIGNIFICANCE OF PHYSICAL EXERCISES' PRACTICING AND RESONS, CONDITIONING IT
}

\author{
Kubaj G.V.
}

Vasyl Stefanyk Precarpathian National University

\begin{abstract}
Purpose: to create pre-conditions for rising effectiveness of physical exercises' practicing by increasing of appropriate medical colleges students' motivation and attitude to role of such trainings in health strengthening and protection. Material: in the research 221 students (105 boys and 116 girls) participated; all they were $3^{\text {rd }}$ year students. Results: Extra curriculum physical exercises' training is much more interesting for boys. With it $50 \%$ of boys and girls like in-college physical culture lessons. The content of such trainings does not facilitate formation of students' position in respect to role of such exercises in health strengthening and protection. There is deficit of students' appropriate knowledge and absence of their understanding of demand in mastering of appropriate knowledge and skills. Conclusions: for removal of detected drawbacks it is necessary to improve organization and content of medical colleges' students' physical education, considering the received data.
\end{abstract}

Key words: knowledge, motives, physical, education, students, medical college.

\section{Introduction}

One of important aspects of normative-legal and instructive-directive documents of national educational system is connected with health strengthening and protection of students [5, 8, 9]. It becomes still more important in case with future medical workers of primary level. It is conditioned by the fact that at the stage of education formation of students' readiness for motivation of their future patients for healthy life style is not of less importance.

In this connection it is necessary to pay attention to one of the most important its components - motor functioning with optimal parameters. This functioning is realized in different forms of physical exercises' practicing [1-3, 13]. Motor functioning is ensured in medical colleges by compulsory trainings, envisaged by curriculum. Physical trainings are conducted twice a week in the form of lessons. Besides there is an opportunity to attend extra curriculum trainings in sport circles by kinds of sports, with optional attendance. In this connection the decisive condition is students' motivation as well as students' practicing of other forms of physical trainings [4, 7, 18-20]: independent individual or group sessions. That is why formation of motivation in medical colleges' students is extremely important task of physical education theory.

The available in special literature sparse data 8, 10-12] witness about 15-17 years old youth's insufficient motor functioning. It is one of reasons of other low indicators, which characterize somatic health, organism systems' functional potentials; condition of physical abilities [14-16]. Pedagogic colleges' readiness for realization of students' health related physical culture training is at level below middle ( $4.7 \pm 0.01$ conv.un.) at the first year. Then, there appears a tendency for reduction with every following year [10]. It was found that in $54.5 \%$ of medical colleges' students vauelogic competence is at low level [8]. Such data point at demand in increasing of their physical education effectiveness. In such case the main task is formation of firm and adequate position in respect to physical exercises' practicing for health protection and strengthening (both personal and future patients').

Thus, the received information witnesses about sparse researches in the studied direction and their fragmentary character. That is why, the researches in the mentioned direction are still important.

\section{Purpose, tasks of the work, material and methods}

The purpose of the research is to create pre-conditions for rising effectiveness of physical exercises' practicing by increasing of appropriate medical colleges students' motivation and attitude to role of such trainings in health strengthening and protection.

The tasks of the research: to substantiate demand in increase of the studied trainings' effectiveness; to determine motivation of medical colleges' students for physical exercises' practicing and their position in respect to role of such trainings in health strengthening and protection; to generalize the received data. In questioning 221 students (105 boys and 116 girls) participated; all they were $3^{\text {rd }}$ year students. Selection was carried out by method of random sampling. We used the worked out by us, considering recommendations of special literature, questionnaire [17].

\section{Results of the research}

The received data witness: in issue of physical exercises' practicing for health strengthening and protection students' position does not concord with specialists' position. In particular, only $27.6 \%$ girls and $65.7 \%$ of boys allocate first place to physical exercises' practicing. Analysis of the received answers showed that in opinion of $34.5 \%$ of girls and $20 \%$ of boys physical exercises' practicing does not enter in three priority kinds. Besides, $20.7 \%$ of girls and $42.8 \%$ of boys definitely consider knowledge about means and methods of organism's state and current potentials' diagnosing

(C) Kubaj G.V., 2015

http://dx.doi.org/10.15561/20755279.2015.0605 
to be unnecessary. Accordingly 51.7 and $28.6 \%$ - could not answer. And it is in spite of the fact that such control is rather important component of healthy life style [1-3, 5, 6, 11, 13, 14].

Such result is to large extent conditioned by students' knowledge and their motivation for realization of such functioning in every day life. The first is proved by answers to questions, connected with future professional functioning: $46.5 \%$ girls and $42.9 \%$ of boys definitely think that knowledge about physical exercises' practicing are unnecessary; accordingly only 27.6 and $28.6 \%$ - prove importance of knowledge about means and methods of organism's diagnosing; 31.7 and $28.6 \%$ - could not answer. For girl, the reason of such knowledge importance is connected with the following: control over own organism's condition $(22.4 \%)$; advices of relatives and friends $(20.7 \%)$. The quantity of boys' such answers was accordingly 54.2 and $20 \%$. $8.6 \%$ of boys called consultation of future patients as the reason. Among girls such variant was absent.

The confirmation of conclusion about students' motivation are the following data: $94.3 \%$ of boys and only $32.8 \%$ of girls practiced some kinds of sports before entering college; as on the moment of questioning accordingly 94.3 and $39.7 \%$ wanted to practice sports. At the same time only $48.3 \%$ of girls and $48.6 \%$ of boys like to attend compulsory physical culture lessons.

In first case the main reason of girls' $(24.2 \%)$ and boys' $(17,1 \%)$ wish to practice sports means opportunity to communicate with other students. Accordingly for $13.8 \%$ and $60 \%$ it means improvement of health. For $14.3 \%$ of boys motive is improvement of physical potentials. Absence of wish $45.6 \%$ of girls is connected with absence of demand, for $5,2 \%$ deficit of free time. For boys, such absence of wish to practice physical culture exercises is connected with deficit of free time $(5,7 \%)$. Concerning physical culture curriculum lessons, the obtained girls' and boys' low results are connected to large extent with their not understanding of demand in such lessons (34.5\% and $14.3 \%$ accordingly). With it one of ways of such situation's overcoming is consideration of students' preferences in content of lessons. For example for $53.5 \%$ of girls and $94.3 \%$ of boys sport games are preferable. For girls - also gymnastic (20.7\%), light athletic (8.6\%) exercises are attractive; for other students - other exercisesупражнения.

Thus, the received data witness about noticeably higher boys' interest to physical exercises in extra-curriculum time; approximately equal quantity of those, who like physical culture lessons $(<50 \%)$. Considering it, the problem of increasing of girls' interest to physical exercises' practicing in different forms is more important. Besides, the received data show that students have no formed clear position in respect of such exercises' role in health strengthening and protection and deficit of appropriate knowledge. Besides, it should be noted that there is insufficient understanding that the mentioned knowledge and skills are extremely necessary for highly qualified medical worker.

\section{Discussion}

The received results are connected with a complex of reasons. In most general form one of them is low effectiveness of formation of girls' and boys' motivation for systemic physical exercises' practicing in different forms in comprehensive educational establishment and in period of studying in medical college. The next reason is practically complete absence in academic programs of professionally oriented and general disciplines, which could give additional knowledge about physical education process's specificities. Deficit of attention to formation of students' knowledge on the regarded aspects (in college and at previous stage of learning) is of not less importance. It concerns also usage of meaningful connections with other academic disciplines.

Demand in consideration of the above delivered is noted by many scientists $[3,5,6,9,13]$. The authors say about importance of healthy life style practicing: knowledge of physical exercises practicing; ability to realize motor functioning with optimal parameters; systemic realization of motor functioning and control over physical condition. To some extent the received data concord with conclusions of other authors [4, 9-11, 14-16, 18] about absence of girls' and boys' belief in following healthy life style; insufficient studying of their valuelogic education in medical colleges; poor formation of theoretical knowledge and skills for application of such knowledge in every day life [8].

Concerning meaningful interdisciplinary connections of different studied disciplines and physical education in formation of valueologic knowledge their realization facilitates strengthening of motivation for such knowledge application in practice [16]. At the same time practically all specialists point at demand in re-understanding of attitude to solution of physical education tasks, connected with formation of students' theoretical knowledge on the regarded problem.

Considering the above said the received experimental data show at demand in perfection of organization and content of physical education of medical colleges' students. Realization of such approach will facilitate achieving of the required result in formation of students' clear position in respect to physical exercises' practicing for health strengthening. Finally, it will permit to strengthen students' motivation for systemic physical functioning of health related orientation and increase their professional fitness level in this aspect.

\section{Conclusions}

1. Most of medical colleges' undergraduates believe in secondary importance of physical culture exercises' practicing for health strengthening and protection in comparison with other effective means. Boys' interest to such practicing is much higher than girls'. The knowledge about methodic of organism's condition and its potentials diagnosing are definitely considered unnecessary by $56.9 \%$ of girls and $14.3 \%$ of boys. 
2. To large extent such result is conditioned by low knowledge level about physical activity of health related orientation: $46.5 \%$ of girls and $42.9 \%$ of boys definitely consider such trainings unnecessary. The second reason is absence of motivation that is reflected in students' answers; unwillingness to attend curriculum physical culture trainings (51.7\% of girls); absence of demand and free time (45.6\%). Absence of demand and free time was marked only by $5.7 \%$ of boys. юношей. $34.5 \%$ of girls and $14.3 \%$ of boys do not understand necessity of such trainings.

3 . The received result points at need in improvement of organization and content of medical colleges' students' physical education. It is necessary to consider the received data, reflecting the following wishes: of $53.5 \%$ of girls and $94.3 \%$ of boys to practice sport games; of $20.7 \%$ and $8.6 \%$ of girls to practice gymnastic and light athletic exercises.

\section{Financing}

The work has been fulfilled in compliance with governmentally financed topic "Theoretical-methodic principles of application of informational, pedagogic and medical-biological means for motor and spiritual development and healthy life style formation" (state registration number 0115U004036).

The further researches shall be directed at determination of approaches to perfection of organization and content of medical colleges' students' physical education. Their realization in appropriate program will facilitate increasing of motivation for the following: systemic use of health related physical functioning in extra curriculum time; formation and practical realization of knowledge and skills of healthy life style in personal aspect and in future professional functioning.

\section{Conflict of interests}

The author declares that there is no conflict of interests.

\section{References:}

1. Bar-Or O, Rouland T. Zdorov'e detej i dvigatel'naia aktivnost': ot fiziologicheskikh osnov do prakticheskogo primeneniia [Children's health and motor functioning: from physiological principles to practical application], Kiev, Olympic Literature; 2009 (in Russian)

2. Bulatova MM. Fitnes i dvigatel'naia aktivnost': problemy i puti resheniia [Fitness and motor functioning: problems and ways of their solution]. Teoriia i metodika fizichnogo vikhovannia i sportu, 2007;1:3-7. (in Russian)

3. Dutchak MV. Sport dlia vsikh v Ukraini [Sports for all in Ukraine], Kiev, Olympic Literature; 2009 (in Ukrainian)

4. Iedinak GA. Stan ta deiaki teoretichni aspekti posilennia motivacii studentiv do sistematichnoi rukhovoi aktivnosti ozdorovchogo spriamuvannia [State of students' motivation for health related systemic motor functioning and some theoretical aspects of its strengthening]. Visnik Prikarpats'kogo nacional'nogo universitetu, 2012;16:34-39. (in Ukrainian)

5. Iermakova TS. Problema formuvannia zdorovogo sposobu zhittia starshoklasnikiv u vitchiznianij pedagogici (druga polovina XX stolittia). Cand. Diss.[Problem of healthy life style formation of senior pupils in domestic pedagogic (second half of 20th century). Cand. Diss.]. Kharkiv; 2010 (in Ukrainian)

6. Ivashchenko LIa, Blagij AL, Usachev IuA. Programmirovanie zaniatij ozdorovitel'nym fitnesom [Programming of health related fitness trainings], Kiev, Kiev, Scientific World; 2008 (in Russian)

7. Matveev LP. Teoriia $i$ metodika fizicheskoj kul'tury [Theory and methodic of physical culture], Moscow; Sportacademypress; 2008 (in Russian)

8. Ostafijchuk IaF. Formuvannia valeologichnikh kompetencij u studentiv medichnikh koledzhiv u procesi fizichnogo vikhovannia. Cand. Diss. [Formation of medical colleges' students' valuelogic competences in process of physical education. Cand. Diss.], Lviv; 2014 (in Ukrainian)

9. Potashniuk IV. Shkola spriiannia zdorov'iu: teoriia, praktika, metodi doslidzhennia [School facilitating health: theory, practice, methods of research], Luts'k, Nadstyr'ia; 2006 (in Ukrainian)

10. Romanchishin OM. Formuvannia gotovnosti studentiv pedagogichnikh koledzhiv do fizkul'turno-ozdorovchoi roboti. Cand. Diss. [Formation of pedagogic colleges' students' readiness for health related physical culture work], Lviv; 2013 (in Ukrainian)

11. Sainchuk MM. Formuvannia cinnisnikh oriientacij v sferi fizichnoi kul'turi i sportu uchniv starshikh klasiv u procesi fizichnogo vikhovannia. Cand. Diss. [Formation of senior pupils' value orientations in process of physical education. Cand. Diss.], Lviv; 2013 (in Ukrainian)

12. Semenova NV. Obgruntuvannia rezhimu rukhovoi aktivnosti studentok 15-17 rokiv z riznim rivnem somatichnogo zdorov'ia. Cand. Diss. [Substantiation of motor regime of 15-17 years age girl students with different level of somatic health. Cand. Diss.], Lviv; 2013 (in Ukrainian)

13. Imas EV, Dutchak MV, Trachuk SV. Strategii i rekomendacii po zdorovomu obrazu zhizni i dvigatel'noj aktivnosti [Strategies and recommendations on healthy life style and motor functioning], Kiev, Olympic Literature; 2013 (in Russian)

14. Tomenko OA. Teoretiko-metodologichni osnovi nespecial'noi fizkul'turnoi osviti uchnivs'koi molodi. Doct. Diss. [Theoretical-methodological principles of pupils' not special physical culture education. Doct. Diss.], Kiev; 2012 (in Ukrainian) 
15. Topilko NIa. Pidvishchennia rivnia somatichnogo zdorov'ia uchniv PTU zasobami fizichnogo vikhovannia. Cand. Diss. [Rising of somatic health level of Vocational technical schools' pupils by means of physical education. Cand. Diss.] Lviv; 2011 (in Ukrainian)

16. Fedorenko IeO. Formuvannia motivacii do special'no organizovanoi rukhovoi aktivnosti starshoklasnikiv. Cand. Diss. [Formation of motivation for specially organized motor functioning of senior pupils. Cand. Diss.], Dnipropetrovs'k; 2012 (in Ukrainian)

17. Shiian BM, Iedinak GA, Petrishin IuV. Naukovi doslidzhennia u fizichnomu vikhovannia ta sporti [Scientific researches in physical education and sports]. Kamenets Podolsky, Ruta; 2013 (in Ukrainian)

18. Iurchishin IuV. Tekhnologiia zaluchennia studentiv do rukhovoi aktivnosti ozdorovchoi spriamovanosti u procesi fizichnogo vikhovannia. Cand. Diss. [Technology of students' involvement in health related motor functioning in process of physical education. Cand. Diss.], Kiev; 2012 (in Ukrainian)

19. Theobald MA. Increasing student motivation: strategies for middle and high school teachers. California: Corwin Press; 2005.

20. Yli-Piipari S, Watt A, Jaakkola T, Liukkonen J, Nurmi J-E. Relationships between physical education students motivational profiles, enjoyment, state anxiety, and self-reported physical activity. Journ. of Sports Science and Medicine. 2009;8:327-336. 


\section{Information about the author:}

Kubaj G.V.; http://orcid.org/0000-0002-4212-3274;

Grigoryano@i.ua; Vasyl Stefanyk Precarpathian National University; 57 Shevchenko str., 76018, Ivano-Frankivsk, Ukraine .

Cite this article as: Кубай $Г$. В. Особенности позиции студентов медицинских колледжей о значении занятий физическими упражнениями для укрепления здоровья и причины их обусловливающие Physical education of students,

http://dx.doi.org/10.15561/20755279.2015.0605

The electronic version of this article is the complete one and can be found online at: http://www.sportpedu.org.ua/html/arhive-e.html

This is an Open Access article distributed under the terms of the Creative Commons Attribution License, which permits unrestricted use, distribution, and reproduction in any medium, provided the original work is properly cited (http://creativecommons.org/licenses/by/4.0/deed.en).

Received: 22.08 .2015

Accepted: 30.08.2015; Published: 10.09.2015 